\title{
PERAN PENYULUH DALAM AGRIBISNIS PERIKANAN AIR PAYAU DI KABUPATEN BANGKALAN MADURA
}

\author{
Hurrul Fikri' ${ }^{1}$, Subekti², Sofia ${ }^{2}$ \\ ${ }^{1}$ Mahasiswa Program Studi Agribisnis, Fakultas Pertanian, Universitas Jember \\ ${ }^{2}$ Staff Pengajar Program Studi Agribisnis, Fakultas Pertanian, Universitas Jember \\ E-mail : Hurrul_fikri@yahoo.co.id
}

\begin{abstract}
Vaname household agri-fishery (RTVE) is a vaname shrimp farming activity undertaken in pool tarps. One of shrimp farmers, who are successful in this business and are now being self-help instructors in collaboration with the government owned fishing instructors to promote these activities, are the shrimp farmers in Kwanyar Sub-district of Bangkalan. This research was aimed to explain : (1) the implementation of extension practices in Vaname Fisheries, (2) the role of extension agents, and (3) the problems during extension practices. This research used qualitative method by using the data analysis model proposed by Miles and Huberman. The results shows: (1) There are differences on extension implementation between PNS and self-help-instructor agents. Equipments, evaluation system, and extension methods are the different aspects of extension implementation. (2) the PNS agents have an optimal role as an instructor and analyst. However, the self-help instructor has an optimal role as instrutor, facilitator, motivator, advisor, surveyor and organizer. (3) the obstacle and problems which were faced by PNS and self-help-instructor are also different. PNS extension agents have much problems in technical terms such as distance, time, facility, extension agents and knowledge problems. Otherwise, self-help-instrucor faced problems especially in human error and outside interventionKeywords: Instructors, Shrimp farmers, Vaname household agri-fishery (RTVE).
\end{abstract}

Keywords: Instructors, Shrimp farmers, Vaname household agri-fishery (RTVE).

\section{PENDAHULUAN}

Sektor perikanan merupakan sektor yang dari jaman dahulu mampu memberikan kontribusi yang menguntungkan bagi devisa negara. Meskipun terjadi berbagai gejolak krisis ekonomi global, sektor perikanan mampu bertahan dan cenderung stabil dibandingkan sektor yang lainnya. Sektor perikanan di Indonesia sangat bervariasi mulai dari bentuk penangkapan (capture) maupun budidaya (culture) semuanya dapat diterapkan dengan baik di wilayah Indonesia. Perikanan di Indonesia terbagi dalam tiga kategori perairan yaitu air asin, air tawar dan air payau (Akhmad et al, 2013).

Menurut Fauzi A (2005), sumber daya perikanan sebagaimana sumber daya alam lainnya, merupakan aset negara yang dapat memberikan sumbangan berarti bagi kesejahteraan suatu bangsa (Wealth of nation). Sampai saat ini kontribusi sumber daya perikanan masih diukur dari sumbangan Produk Domestik Bruto (PDB), devisa negara, dan penyerapan tenaga kerja. Dengan kata lain kontribusi sumber daya perikanan masih terbatas pada sisi input yang dibutuhkan dan output yang dihasilkan. Dengan hanya melihat beberapa indokator tersebut, kontribusi sumber daya perikanan masih dikatakan relatif kecil. Sebagai contoh, kontribusi perikanan Indonesia terhadap PDB masih berkisar disekitar angka 2\% sementara sumbangannya terhadap devisa, meski dalam angka nominal relatif besar, yakni US dollar 3 miliar, secara proporsional relatif kecil.

Kabupaten Bangkalan sebagai kabupaten yang mayoritas kecamatannya berada di pesisir mendukung kegiatan yang berada di pesisir seperti kegiatan perikanan tambak, salah satunya yaitu perikanan tambak air payau. Air payau adalah campuran antara air tawar dan air laut (air asin), jika kadar garam yang terkandung dalam satu liter air antara 0,5-30 gram, maka air tersebut bisa dikatakan sebagai air payau. Kondisi geografis Kabupaten Bangkalan yang mendukung kegiatan perikanan tambak air payau memberikan nilai lebih untuk melakukan kegiatan tersebut. Salah satu komoditas unggulan air payau dan memiliki produksi yang tinggi di 
Kabupaten Bangkalan yaitu komoditas udang vaname. Menurut (Supono, 2011), udang putih (L. Vannamei) merupakan spesies introduksi yang dibudidayakan di Indonesia. Udang putih yang dikenal masyarakat dengan vaname ini berasal dari Amerika Tengah. Negara negara di Amerika Tengah dan Selatan seperti Ekuador, Venezuela, Panama, Brasil dan Meksiko sudah lama membudidayakan udang yang dikenal juga sebagai pasific white shrimp.

Usaha budidaya udang vaname baru diperkenalkan pada tahun 2000 di Indonesia, sejak turunnya produksi udang windu. Industri budidaya udang windu di Indonesia telah berkembang sejak tahun 1980 dan mencapai prestasi yang membanggakan pada tahun 1994 sebagai negara yang memproduksi dan menekspor udang windu terbesar kedua di dunia. Udang windu saat ini tidak berkembang lagi karena terserang berbagai macam penyakit udang yang ganas seperti penyakit white spot atau virus bintik putih (Chamberlain dalam Kharisma, A dan Abdul, 2012)

Petani udang vaname di Kecamatan Kwanyar Kabupaten Bangkalan merupakan pionir dalam menerapkan pola rumah tangga vaname (RtVe) atau budidaya udang vaname yang dilakukan di kolam terpal dengan memanfaatkan pekarangan rumah maupun pekarangan sempit dan menjadi petani udang vaname yang sukses. Petani udang yang sukses tersebut menjadi penyuluh perikanan swadaya dan melaksanakan penyuluhan dengan sukarela (tanpa digaji) untuk membagikan ilmu, informasi serta pengalamannya agar keberhasilan yang petani dapatkan tersebut bisa diikuti oleh petani udang lainnya. Penyuluh perikanan swadaya menjadi partner dan bekerja sama dengan penyuluh perikanan Pegawai Negeri Sipil (PNS) khususnya di regional Kecamatan Kwanyar untuk melakukan penyuluhan.

Menurut UU Penyuluhan No. 16 Tahun 2006, penyuluhan pertanian, perikanan, kehutanan yang selanjutnya disebut penyuluhan adalah proses pembela- jaran bagi pelaku utama serta pelaku usaha agar mereka mau dan mampu menolong dan mengorganisasikan dirinya dalam mengakses informasi pasar, teknologi, permodalan, dan sumberdaya lainnya, sebagai upaya untuk meningkatkan produktivitas, efisiensi usaha, pendapatan, dan kesejahteraannya, serta meningkatkan kesadaran dalam pelestarian fungsi lingkungan hidup. Selain itu, menurut UU No. 16 Tahun 2006 (SP3K) Pasal 8 butir (1) kelembagaan penyuluhan pertanian terdiri atas tiga lembaga, yaitu penyuluhan pemerintah, penyuluhan swasta dan penyuluhan swadaya. Lembaga penyuluhan yang difokuskan pada penelitian ini adalah penyuluhan pemerintah dan penyuluhan swadaya. Penyuluh pegawai negeri sipil yang se lanjutnya disebut penyuluh PNS adalah pegawai negeri sipil yang diberi tugas, tanggung jawab, wewenang, dan hak secara penuh oleh pejabat yang berwenang pada satuan organisasi lingkup pertanian, perikanan, atau kehutanan untuk melakukan kegiatan penyuluhan (pasal 1 butir 19). Penyuluh swadaya adalah pelaku utama yang berhasil dalam usahanya dan warga masyarakat lainnya yang dengan kesadarannya sendiri mau dan mampu menjadi penyuluh (pasal 1butir 21).

Penyuluhan memberikan dampak yang positif dalam kegiatan agribisnis perikanan rumah tangga vaname (RtVe). Menurut Downey dan Erickson dalam Galuh dan Ivan, (2014), agribisnis adalah kegiatan yang berhubungan dengan penanganan komoditi pertanian dalam arti luas, yang meliputi salah satu atau keseluruhan dari rantai produksi, pengolahan masukan dan keluaran produksi (agroindustri), pemasaran masukan-keluaran pertanian dan kelembagaan panunjang usaha, yang dimaksud berhubungan adalah kegiatan usaha yang menunjang kegiatan pertanian dan kegiatan usaha yang ditunjang oleh kegiatan pertanian. Oleh karena itu agribisnis didefinisikan sebagai tiga sektor secara ekonomi saling berkaitan. Ketiga sektor agribisnis tersebut adalah (a) the input sup- 
ply sector, (b) the farm production sector, dan (c) the product marketing sector

Pelaksanaan Penyuluhan yang dilakukan oleh penyuluh perikanan harus dilakukan dengan maksimal terhadap petani udang vaname yang ada di Kecamatan Kwanyar agar memberikan perubahan yang mengarah kepada perubahan yang positif, akan tetapi adanya kendala dilapangan dapat menghambat dari keberhasilan penyuluhan. Apabila kendala tersebut dapat diminimalisir maka kemungkinan besar penyuluhan yang direncanakan akan berhasil sesuai dengan harapan, sehingga potensi agribisnis perikanan rumah tangga vaname (RtVe) dapat berkembang dan keberhasilan dalam agribisnis perikanan rumah tangga vaname (RtVe) yang dilakukan oleh petani udang akan terwujud. Pada akhirnya peran penyuluh yang sangat besar sebagai agent of change akan dapat terimplementasi sepenuhnya terhadap sasaran penyuluhan, dan dapat membangun proses perubahan perilaku (Behaviour) yang merupakan perwujudan dari pengetahuan, sikap, dan keterampilan.

Peran adalah serangkaian perilaku yang diharapkan pada seseorang sesuai dengan posisi sosial yang diberikan baik secara formal maupun secara informal. Peran didasarkan pada preskripsi (ketentuan) dan harapan peran yang menerangkan apa yang individu-individu harus lakukan dalam suatu situasi tertentu agar dapat memenuhi harapan-harapan mereka sendiri atau harapan orang lain menyangkut peran-peran tersebut. Peran dapat didefinisikan sebagai "expectations about appropriate behavior in a job position (leader, subordinate)". Ada dua jenis perilaku yang diharapkan dalam suatu pekerjaan, yaitu: Role perception: yaitu persepsi seseorang mengenai cara orang itu diharapkan berperilaku; atau dengan kata lain adalah pemahaman atau kesadaran mengenai pola perilaku atau fungsi yang diharapkan dari orang tersebut, dan Role expectation: yaitu cara orang lain menerima perilaku seseorang dalam situasi tertentu. Dengan peran yang dimainkan seseorang dalam organisasi, akan terbentuk suatu komponen penting dalam hal identitas dan kemampuan orang itu untuk bekerja. Dalam hal ini, suatu organisasi harus memastikan bahwa peran-peran tersebut telah didefinisikan dengan jelas (Hermansyah, 2015).

Safrida et al (2015) menyatakan bahwa penyuluh perikanan dalam pengembangan sektor perikanan di Kabupaten Aceh Utara memiliki peran. Peran yang dimiliki penyuluh sangatlah besar, mulai dari penyampaian informasi perikanan, penyaluran sarana produksi perikanan, serta peran penyuluh perikanan dalam proses pengolahan dan pemasaran hasil perikanan di Kabupaten Aceh Utara. Penelitian ini bertujuan untuk : 1) mengetahui pelaksanaan penyuluhan agribisnis perikanan; 2) peran penyuluh agribisnis perikanan; 3) evaluasi penyuluhan pertanian agribisnis perikanan

\section{METODE PENELITIAN}

Penelitian ini dilakukan di Kecamatan Kwanyar Kabupaten Bangkalan dikarenakan terdapat petani udang sukses dan menjadi pionir dari berdirinya konsep agribisnis perikanan rumah tangga vaname (RtVe), menjadi kecamatan percontohan dalam agribisnis perikanan rumah tangga vaname (RtVe) dan memiliki penyuluh perikanan yang aktif.

Penelitian ini menggunakan metode kualitatif, dan menggunakan pendekatan studi kasus. Penentuan Informan kunci menggunakan teknik purposive method sedangkan informan tambahan dengan cara snowball. Informan kunci yaitu penyuluh perikanan PNS bernama Besuki dan penyuluh perikanan swadaya bernama Moh Muhlis. Informan tambahan yaitu petani udang yang pernah disuluh oleh penyuluh yaitu Moh Muhlis, Mahmud, Muhlis, Ainun Najib, Mahmud, dan Hasym. Selain petani, terdapat perangkat gabungan kelompok tani yang menjadi informan kunci seperti ketua, sekretaris dan bendahara. 
Peneliti untuk mendapatkan data, menggunakan tiga pendekatan yaitu wawancara mendalam (indepth interview), observasi dan dokumen. Peneliti menguji keabsahan data menggunakan triangulasi teknik. Menurut Sugiyono (2014), triangulasi teknik untuk menguji kreadibilitas data dilakukan dengan cara mengecek data yang diperoleh kepada sumber yang sama dengan teknik yang berbeda. Triangulasi teknik yang digunakan dalam penelitian ini yaitu data yang diperoleh dari wawancara, di cek kembali dengan observasi, dan dokumen.

Metode analisis data menggunakan model Miles dan Huberman. Miles dan Huberman (dalam Sugiyono, 2014) mengemukakan bahwa aktifitas dalam analisis data kualitatif dilakukan secara interaktif dan berlangsung secara terus menerus sampai tuntas, sehingga datanya sudah jenuh. Aktivitas dalam analisis data, yaitu data reduction, data display, dan conclusion.

\section{HASIL DAN PEMBAHASAN}

\section{Pelaksanaan Penyuluhan Perikanan}

Pelaksanaan penyuluhan perikanan merupakan suatu hal yang sangat penting untuk diperhatikan, karena hal tersebut merupakan salah satu faktor yang dapat memperlancar keberhasilan dalam tujuan diberlakukannya penyuluhan. Jika penyuluhan yang dilakukan oleh penyuluh tersebut dapat terlaksana dengan optimal hal tersebut akan berdampak terhadap penerimaan informasi serta wawasan yang diterima oleh petani udang.

Pada pembahasan ini akan di uraikan tentang pelaksanaan penyuluhan perikanan yang dilaksanakan oleh penyuluh perikanan PNS dan penyuluh perikanan swadaya. Penyuluh perikanan PNS di Kecamatan Kwanyar yaitu Besuki menjadi penyuluh perikanan di wilayah Kecamatan Kwanyar pada tahun 2015, sedangkan penyuluh perikanan swadaya yaitu Moh Muhlis menjadi penyuluh semenjak keberhasilannya dalam berbudidaya udang vaname.
Pelaksanaan Penyuluhan Perikanan Oleh Penyuluh Perikanan PNS

a. Metode Penyuluhan

Metode sebagai cara untuk menyampaikan materi (Isi pesan) oleh penyuluh kepada sasaran. Penyuluh menggunakan sistem latihan dan kunjungan (LAKU). Menteri Pertanian (2007) sistem kerja LAKU, latihan bagi penyuluh pertanian diselenggarakan di BPP atau ditempat lain dengan jadwal sekali dalam dua minggu. Latihan tersebut diselenggarakan secara teratur, terarah dan berkelanjutan. Proses latihan (belajar-mengajar) difasilitasi oleh penyuluh pertanian yang menguasi materi, maupun tenaga ahli dari lembaga lainnya. Kunjungan penyuluh pertanian kepada kelompoktani dilakukan selama 4 (empat) hari kerja dalam seminggu, setiap penyuluh membina 8-16 kelompoktani dan dijadualkan mengunjungi setiap kelompok sekali dalam 2 minggu. Dengan kunjungan kerja ini diharapkan seorang penyuluh pertanian dapat mempengaruhi 100 orang petani per kelompoktani.

Latihan yang didapat oleh penyuluh perikanan PNS yang memiliki wilayah kerja di Kecamatan Kwanyar Kabupaten Bangkalan tidaklah rutin sehingga berdampak terhadap kualitas dari penyuluh. Sedangkan untuk kunjungan yang dilakukan oleh penyuluh perikanan PNS, dalam satu bulan dilakukan 4-5 kali pertemuan. Kunjungan yang dilakukan menggunakan metode kontak tani yaitu terhadap petani udang sukses yang menjadi pionir dari berdirinya rumah tangga vaname (RtVe) dan pertemuan yang dilakukan di Kelompok Budidaya Ikan (POKDAKAN) yang diketuai oleh pionir tersebut.

\section{b. Materi Penyuluhan}

Menurut Mardikanto, T (1992) materi penyuluhan pada hakekatnya merupakan segala pesan yang ingin dikomunikasikan oleh seorang penyuluh kepada masyarakat sasarannyaDengan kata lain, materi penyuluhan adalah semua pesan yang akan disampai- 
kan dalam proses untuk pembangunan.

Materi yang disampaikan oleh penyuluh perikanan PNS didapat dari internet, segala informasi yang didapat merupakan informasi yang berhubungan dengan agribisnis perikanan rumah tangga vaname (RtVe). Selain itu penyuluh juga melihat dari website Pusluh.kkp.go.id dikarenakan web tersebut merupakan situs resmi pusat penyuluhan kementerian kelautan dan perikanan yang memberikan berbagai informasi tentang berbagai materi dan pelaksanaan penyuluhan perikanan.

\section{c. Perlengkapan Penyuluhan}

Sebagai suatu sistem pendidikan non formal, yaitu suatu sistem pendidikan terpogram di luar sekolah, kegiatan penyuluhan mutlak memerlukan perencanaan yang jelas mengenai program pendidikan yang akan dilaksanakan. Tentang hal ini, dalam setiap melaksanakan kegiatan penyuluhan, seorang penyuluh tidak hanya cukup menetapkan topik materi penyuluhan dan merancang metode yang akan diterapkan. Tetap, yang tidak boleh dilupakan adalah persiapan tentang perlengkapan penyuluhan (Mardikanto, T, 1992)

Perlengkapan penyuluhan seperti alat-alat bantu sebagai alat dalam membantu penyampaian informasi terhadap sasaran. Perlengkapan penyuluhan membantu dalam memperlancar penyuluhan, dan memperjelas dari materi yang akan disampaikan agar informasi tersebut lebih mudah untuk dipahami oleh sasaran. Perlengkapan penyuluhan perikanan menggunakan laptop, HP, microphone (pengeras suara) dan proyektor.

\section{d. Perencanaan Program Penyuluhan}

Perencanaan adalah suatu proses pengambilan keputusan yang berdasarkan fakta, mengenai kegiatan kegiatan yang harus dilaksanakan demi tercapainya tujuan yang diharapkan atau dikehendaki (Mardikanto, T, 1992). Penyuluh perikanan PNS sebelum melakukan kegiatan penyuluhan perikanan, membuat rencana kerja terlebih dahulu.

Rencana kerja memberikan panduan yang dapat dijadikan acuan dalam melakukan penyuluhan perikanan. Penyuluhan yang dilakukan oleh penyuluh perikanan PNS didasarkan rencana kerja yang didapat dari Badan Koordinasi Penyuluhan (BAKORLUH). BAKORLUH merupakan badan koordinasi penyuluhan (pertanian, perikanan dan kehutanan). Sekretariat BAKORLUH/ kelembagaan yang membidangi dari penyuluhan provinsi, bertanggung jawab dalam pembinaan sistem kerja LAKU.

Rencana kerja yang didapat dari Badan Koordinasi Penyuluhan (BAKORLUH) diterapkan dalam jangka waktu satu tahun atau biasa disebut dengan Rencana Kerja Tahunan Penyuluh (RKTP).

\section{e. Evaluasi Penyuluhan}

Kata "evaluasi” dalam kehidupan sehari hari sering diartikan sebagai padanan istilah "penilaian", yaitu suatu tindakan pengambilan keputusan untuk menilai sesuatu obyek, keadaan, peristiwa, atau kegiatan tertentu yang sedang diamati (Hornby dan Parnwell dalam Mardikanto, T, 1992).

Evaluasi penyuluhan akan mendapatkan sebuah kesimpulan dan menilai tentang segala sesuatu yang terjadi terhadap penyuluhan yang dijalankan. Evaluasi akan menjadi kegiatan yang cukup penting karena akan memberikan sebuah gambaran, arahan terhadap kegiatan lanjutan yang perlu dilakukan.

Penyuluh perikanan PNS melakukan evaluasi satu tahun sekali. Sebelum dilakukan evaluasi, terlebih dahulu penyuluh perikanan PNS mengirimkan laporan setiap 3 bulan. Laporan tersebut dikirim ke BAKORLUH. Evaluasi yang dilakukan adalah evaluasi sumatif yaitu evaluasi yang dilakukan diakhir atau sesudah penyuluhan selesai dilaksanakan. Pelaksanaan Penyuluhan Perikanan Oleh Penyuluh Perikanan Swadaya Menurut UU No 16 tahun 2006, penyuluh swadaya adalah pelaku utama 
yang berhasil dalam usahanya dan warga masyarakat lainnya yang dengan kesadarannya sendiri mau dan mampu menjadi penyuluh.

Penyuluh perikanan swadaya di Kecamatan Kwanyar adalah Moh Muhlis. Selain menjadi penyuluh perikanan swadaya, Moh Muhlis juga menjadi pionir dari berdirinya konsep agribisnis perikanan rumah tangga vaname (RtVe) dan menjadi ketua dari Kelompok Budidaya Ikan (POKDAKAN) bina usaha. Moh Muhlis mulai menjadi penyuluh perikanan swadaya, ketika berhasil dalam kegiatan agribisnis perikanan rumah tangga vaname (RtVe).

\section{a. Metode Penyuluhan}

Metode yang dilakukan oleh penyuluh perikanan swadaya yaitu perorangan atau person to person dan kelompok. Pelaksanaan penyuluhan perikanan dengan cara person to person terjadi ketika petani secara langsung meminta pertolongan dalam pembuatan kolam terpal, dan ingin mengetahui ilmu yang harus dipelajari dalam kegiatan agribisnis perikanan rumah tangga vaname (RtVe), dari permintaan tersebut terjadi kontak komunikasi secara personal antara penyuluh sebagai komunikator dan petani udang sebagai komunikan, sehingga beberapa tujuan dari penyuluhan seperti mengkomunikasikan (to inform), dan mendidik (to educate) dapat diiplementasikan.

Metode lainnya yaitu dengan cara pertemuan. Penyuluh perikanan swadaya menyebut kegiatan ini sebagai kegiatan clasroom. Penyuluh perikan swadaya melakukan pertemuan di gardu milik penyuluh perikanan swadaya yang dekat dengan kolam. Kelompok yang menjadi sasarannya yaitu kelompok yang memiliki persamaan dalam kegiatan agribisnis perikanan rumah tangga vaname (RtVe) atau kelompok petani udang. Petani udang tersebut merupakan petani binaan dari penyuluh perikanan swadaya yang tersebar di beberapa desa di wilayah Kecamatan Kwanyar yang berada di daerah pesisir seperti Desa Kwanyar Barat, Desa Pesanggrahan, Desa Karang ayar, Desa Batah Timur dan Desa Batah Barat

\section{b. Materi Penyuluhan}

Materi yang disampaikan oleh penyuluh perikanan swadaya didapat awal perjalanan budidaya hingga keberhasilan dalam agribisnis perikanan rumah tangga vaname (RtVe). Penyuluh perikanan swadaya memiliki Standard Operating Procedure (SOP). SOP tersebut didapat dari perjalanan budidaya saat mencoba (try) dan gagal (error). SOP diterapkan saat melakukan penyuluhan perikanan khususnya dalam agribisnis perikanan RtVe.

Materi yang disampaikan oleh penyuluh perikanan swadaya terkait agribisnis perikanan rumah tangga vaname (RtVe) berpedoman kepada SOP. Selain berpedoman kepada SOP, materi juga didapat dari pihak swasta, salah satunya dari PT. Central Proteina Prima Tbk atau $\mathrm{CP}$ Prima. Materi yang didapat dari $\mathrm{CP}$ Prima yaitu materi tentang pengendalian hama dan penyakit dalam kegiatan budidaya udang vaname.

\section{c. Perlengkapan Penyuluhan}

Alat bantu penyuluhan perikanan swadaya yaitu laptop. Laptop mempunyai manfaat dikarenakan ada beberapa materi tentang agribisnis perikanan rumah tangga vaname (RtVe) yang tersimpan di laptop tersebut.

Perlengkapan yang digunakan dalam melakukan penyuluhan perikanan yang diadakan dalam kegiatan classrom hanya menggunakan laptop. Proyektor didapat ketika penyuluh perikanan swadaya dalam melakukan kegiatan classroom berkolaborasi dengan penyuluh dari pemerintah maupun dari penyuluh perikanan swasta, sedangkan apabila ada petani ingin dibuatkan kolam terpal, petani sudah menyiapkan peralatan seperti alat dan bahan yang digunakan. 


\section{d. Perencanaan Program Penyuluhan}

Rencana kerja yang dilakukan oleh penyuluh perikanan yaitu dengan spontan. Penyuluhan yang berisi materi tentang agribisnis perikanan rumah tangga vaname (RtVe) dilakukan secara spontan ketika ada petani yang ingin dimintai tolong dalam pembuatan kolam terpal dan ingin belajar lebih dalam tentang kegiatan agribisnis perikanan rumah tangga vaname (RtVe) .

Rencana kerja di dapat dengan cara spontan yaitu ketika ada petani meminta tolong untuk pembuatan kolam terpal dan memintai pembinaan bagaimana cara untuk melakukan kegiatan agribisnis perikanan rumah tangga vaname (RtVe), maka rencana kegiatan akan dipikirkan dengan mempertimbangkan waktu yang tepat untuk melaksanaan kegiatan penyuluhan perikanan seperti pembuatan kolam terpal serta pembinaan yang dilakukan tersebut. Pelaksanan penyuluhan perikanan yang dilaksakan oleh penyuluh perikanan swadaya berpedoman pada SOP.

Ketika rencana kerja sudah di buat dan pelaksaaan penyuluhan perikanan sudah terjadwal, pelaksanaan penyuluhan perikanan khususnya kepada petani udang, selanjutnya berpedoman dari SOP mulai dari persiapan kolam hingga ke penebaran benur.

Persiapan awal kolam terpal apabila pertama kali dalam membuat kolam, maka terlebih dahulu terpal dicuci, hal ini untuk menghilangkan kadar kimia yang ada di terpal. Apabila kolam sudah berjalan atau pernah di lakukan kegiatan budidaya udang vaname sebelumnya maka tahap pencucian kolam tersebut dilewati.

Persiapan kolam sesudah panen, yaitu kolam dikeringkan. Pengeringan kolam kurang lebih satu minggu. Setelah pengeringan dilakukan pembersihan kolam yaitu pembersihan lumut-lumut yang masih ada di kolam. Pengeringan membantu dalam pengelupasan lumut-lumut, jadi untuk pembersihannya lebih mudah. Apabila tahap tersebut sudah terlewati maka dilakukan tahap selanjutnya yaitu tahap pengi- sian air.

Pengisian air minimal satu meter. Sebelum air masuk ke kolam terlebih dahulu di endapkan di tandon. Setelah masuk ke tandon lalu di isi ke kolam, hal ini diaplikasikan agar air yang masuk ke dalam kolam lebih jernih dan bersih.

Apabila air sudah masuk lalu dilakukan sterilisasi. Sterilisasi kurang lebih 10-15 hari. Pertama yang harus dimasukkan dalam kolam yaitu kupri (dikenal sebagai algisida butiran, disebut juga butiran tajam berwarna biru atau batu biru. Algisida sebagai bahan kimia yang digunakan untuk menghambat atau menghentikan pertumbuhan alga) diaplikasikan pada pagi hari, dan nufaq (merupakan pestisida racun lambung dan pernafasan yang digunakan pada tambak udang dengan tujuan untuk mengendalikan vektor penyakit virus jambret Mesopodopsis sp.) diaplikasikan pada sore hari dan diberikan pada hari yang sama, keesokan harinya pengaplikasian kaporit. Setelah tahap ini selesai selanjutnya penumbuhan plankton.

Penumbuhan plankton dengan cara pemberian fermentasi, pemberian super $\mathrm{nb}$, dan pemberian probiotik. Fermentasi menggunakan dedak padi dicampur dengan tetes tebu. Dedak padi adalah hasil samping penggilingan padi, sedangkan tetes tebu atau molases merupakan sisa hasil dari proses pengolahan pabrik gula. Pembuatan fermentasi yaitu ketika dedak dan tetes tebu dicampur dan dibuat sampai halus, lalu ditutup rapat dan didiamkan. Ditutup rapat agar tidak ada udara yang masuk selama kurang lebih 24 jam. Setelah fermentasi berhasil, selanjutnya fermentasi ditebar, proses kesuksesan fermentasi ditandai dengan bau seperti tape. Apabila fermentasi tidak berhasil, maka akan dibuat kembali fermentasi tersebut sampai berhasil. Sesudah fermentasi selesai lalu kolam dimasukkan super nb. Super nb untuk awal 0,5 ppm. Super nb diaplikasikan di pagi hari. Selanjutnya pemberian probiotik yaitu untuk awal 0,5 ppm. Pemberian super nb dan probiotik selanjutnya tergantung dari kon- 
disi air, pada umur 2 bulan ke atas, semakin lama budidaya kondisi perairan juga tidak stabil, faktornya didukung oleh pakan yang masuk. Semakin banyak pakan yg masuk kondisi air akan semakin tidak stabil, cara menstabilkan memakai probiotik dan super nb. Takaran super nb dan probiotik tidak monoton tergantung pada kondisi air, apabila plankton yang ada cenderung mati solusinya diperbarui memakai super nb, apabila air terlalu pekat bisa dikatakan plankton terlalu berlebihan solusinya memakai probiotik. Plankton dapat dilihat dari partikel ketika air berasa kasar maka sudah ada plankton yang mati. Cara lain dengan menggunakan alat ukur kecerahan, dengan normal kecerahan sekitar 30, 35, 40. Apabila penumbuhan plankton sudah selesai selanjutnya adalah penebaran benur.

Penebaran benur diaplikasikan ketika plankton dinilai sudah tumbuh. Sebelum dilakukan penebaran, benur harus diadaptasikan terlebih dahulu untuk menyesuaikan salinitas, suhu, dan ph setelah salinitasnya sama selanjutnya benur ditebar. Sebelumnya di pindah terlebih dahulu ke ember dengan isian beberapa kantong lalu diukur salinitasnya dan diukur juga salinitas dikolam, apabila tidak sama maka disamakan terlebih dahulu, caranya dengan mengambil air di kolam terus dimasukkan ke dalam ember tersebut secara sedikit demi sedikit. Cara lain untuk menyamakan salinitas, suhu, dan ph yaitu biasanya cukup menyeburkan kantong plastik yang berisikan benur diisi sampai kantong plastik tersebut mengembun selanjutnya dibuka plastiknya di isi air dikolam perlahan sampai salinitasnya sama. Salinitas atau tingkat keasinan atau kagar garam sangat penting dikarenakan salinitas sangat berpengaruh terhadap kehidupan udang vaname. Normal salinitas untuk udang vaname kurang lebih 30 .

\section{e. Evaluasi Penyuluhan Perikanan}

Menurut Ban dan Hawkins (1999), Evaluasi adalah alat manajemen yang berorientasi pada tindakan dan proses. In- formasi yang dikumpulkan kemudian dianalisis sehingga relevansi dan efek serta konsekuensinya ditentukan sesistematis dan seobjektif mungkin. Data tersebut digunakan untuk memperbaiki kegiatan sekarang dan yang akan datang seperti dalam perencanaan, program, pengambilan keputusan, dan pelaksanaan program untuk mencapai kebijaksanaan penyuluhan yang lebih efektif. Data tersebut mencakup penentuan penilaian keefektifan kegiatan dibanding dengan sumber daya yang digunakan

Evaluasi yang dilakukan oleh penyuluh perikanan swadaya yaitu evaluasi sumatif atau evaluasi yang dilakukan setelah penyuluhan selesai dilaksanakan.

\section{Peran Penyuluh Perikanan}

Penyuluhan merupakan keterlibatan seseorang untuk melakukan komunikasi informasi secara sadar dengan tujuan membantu sesamanya memberikan pendapat sehingga bisa membuat keputusan yang benar. Metode dalam penerapan penyuluhan antara lain metode penyuluhan massa, metode penyuluhan kelompok, dan metode penyuluhan individu atau tatap muka. Peranan utama penyuluhan di banyak negara pada masa lalu dipandang sebagai ahli teknologi dari peneliti ke petani. Akan tetapi sekarang peranan penyuluhan lebih dipandang sebagai proses membantu petani untuk mengambil keputusan sendiri dengan cara menambah pilihan bagi mere$\mathrm{ka}$, dan dengan cara menolong mengembangkan wawasan mengenai konsekuensi dari masing-masing pilihan tersebut (Ban dan Hawkins 1999).

Segala bentuk peningkatan pengetahuan dan pengembangan wawasan yang diperlukan oleh petani juga didapat dari diadakannya penyuluhan yang dilakukan oleh peyuluh. Penyuluh sebagai salah satu inisiator dalam peningkatan wawasan dan ilmu pengetahuan terhadap petani udang sehingga penyuluh perikanan memiliki peran yang penting dalam pengimplementasiannya. Pada pembahasan ini diuraikan 
tentang peran penyuluh perikanan yang dilaksanakan oleh penyuluh perikanan PNS dan penyuluh perikanan swadaya dalam agribisnis perikanan rumah tangga vaname (RtVe).

Peran Penyuluh Perikanan PNS

\section{a. Penyampaian informasi}

Peran yang dilakukan oleh penyuluh perikan PNS khususnya dalam agribisnis perikanan rumah tangga vaname (RtVe) yaitu menyampaikan informasi. Informasi biasanya secara langsung diberikan kepada petani rumah tangga vaname, informasi tersebut dinilai penyuluh sebagai informasi yang berguna untuk petani rumah tangga vaname agar lebih antisipasi dalam melakukan kegiatan rumah tangga vaname.

Kunjungan yang dilakukan oleh penyuluh perikanan PNS dengan menyampaikan materi serta informasi. Salah satu bentuk informasi yang disampaikan yaitu adanya suatu penyakit atau virus udang vaname yang melanda di daerah Jawa Barat. Informasi tersebut disampaikan kepada petani udang vaname, hal ini memberikan informasi agar petani harus lebih hati hati karena penyakit mulai menyerang (endemi).

Meskipun peran penyuluh perikanan sebagai penyampaian informasi memiliki nilai positif akan tetapi apabila informasi tersebut kurang cepat disampaikan maka petani menilai informasi tersebut tidak baru lagi, untuk itu hal yang harus dilakukan penyuluh perikanan PNS lebih kepada penyampaian informasi yang baru dan informasi tersebut harus cepat disampaikan ke petani udang. Selain dari penyampaian informasi tentang adanya suatu penyakit maupun virus, penyebaran informasi yang disampaikan oleh penyuluh perikanan PNS salah satunya yaitu informasi tentang penguatan Kelompok Budidaya Ikan (POKDAKAN) agar lembaga tersebut tetap berjalan.

\section{b. Jembatan Penghubung}

Peran penyuluh perikanan PNS yaitu sebagai jembatan penghubung. Jembatan penghubung merupakan penyuluh menjembatani antara satu pihak dengan pihak lainnya.Jembatan penghubung yang dimaksud dan dilakukan oleh penyuluh perikanan PNS yaitu penyuluh menjadi jembatan penghubung antara pemerintah kepada petani dan jembatan penghubung petani dengan tengkulak.

Penyuluh sebagai jembatan penghubung antara pemerintah dengan petani dilakukan ketika adanya suatu classrom atau studi banding yang dipelopori oleh pemerintah. Penyuluh memberitahukan dan mendatangi langsung petani yang diikutsertakan dalam kegiatan clasroom atau studi banding tersebut. Peran penyuluh perikanan PNS sebagai jembatan penghubung juga menghubungkan antara petani dengan tengkulak.Tengkulak datang dari wilayah Gresik, Sidoarjo, Pasuruan, Sampang dan orang orang di sekitar tempat budidaya udang vaname.

Peran penyuluh sebagai jembatan penghubung apabila dilaksanakan dengan konsisten akan membantu dari semua udang vaname yang berjumlah kurang lebih 40 sampai 50 orang petani yang berada di Kecamatan Kwanyar. Apabila peran tersebut tetap dilaksanakan dengan konsisten maka akan lebih mempermudah dalam melakukan pemasaran pada kegiatan agribisnis perikanan rumah tangga vaname (RtVe).

\section{c. Pembimbing}

Peran penyuluh perikanan PNS dalam agribisnis rumah tangga vaname (RtVe) di Kecamatan Kwanyar yaitu membimbing dalam pembuatan proposal. Peran penyuluh dalam membimbing, memberikan dampak yang positif kepada petani udang dalam pembuatan proposal yang nantinya digunakan untuk mendapatkan bantuan dari pemerintah. Bantuan berupa modal maupun alat alat yang digunakan dalam kegiatan agribisnis perikanan rumah tangga vaname (RtVe).

Bantuan yang didapat adalah modal yang digunakan dalam kegiatan agribisnis perikanan rumah tangga vaname (RtVe) se- 
dangkan bantuan lain berupa alat-alat perlengkapan dalam kegiatan tersebut seperti refrakto (alat untuk mengukur kadar garam) dan ph (alat untuk mengukur tingkat keasaman) dan lain sebagainya.

\section{d. Penganalisa}

Penganalisa menurut Mardikanto, T (1992) yang selalu melakukan pengamatan terhadap keadaan (sumberdaya alam, perilaku masyarakat, kemampuan dana, dan kelembagaan yang ada) dan masalah masalah serta kebutuhan-kebutuhan masyarakat sasaran, dan melakukan analisis tentang alternatif pemecahan masalah/pemenuhan kebutuhan-kebutuhan tersebut.

Analisa yang dilakukan oleh penyuluh perikanan PNS apabila tidak ada kendala di lapangan penyuluh menganalisa di keuangan seperti hitungan modal, untung atau rugi. Apabila ada kendala-kendala saat dilangan seperti penyakit, cuaca yang tidak mendukung maka peyuluh mencarikan alternatif pemecahan masalah seperti sirkulasi air serta memakai obat sterilisasi.

Peran Penyuluh Perikanan Swadaya

Peran serta penyuluh perikanan swadaya sebagai mitra dari penyuluh perikanan Pegawai Negeri Sipil (PNS) memberikan dampak yang positif terhadap kegiatan agribisnis perikanan rumah tangga vaname yang dilakukan oleh petani udang. Penyuluh perikanan swadaya di Kecamatan Kwanyar tersebut sebelumnya adalah petani udang vaname yang sukses dalam budidaya udang vaname dengan menerapkan pola rumah tangga vaname (RtVe).

\section{a. Pendidik}

Penyuluh perikanan swadaya memiliki peran sebagai pendidik atau seseorang yang memberikan pendidikan. Pendidikan sebagai suatu proses pembelajaran bagi setiap individu untuk mencapai pengetahuan dan pemahaman yang lebih tinggi mengenai obyek tertentu dan spesifik.

Petani binaan penyuluh perikanan swadaya tersebar di berbagai daerah mu- lai daerah di Kecamatan Kwanyar maupun dari luar Kecamatan Kwanyar. Penyuluh perikanan swadaya dikatakan guru dikarenakan banyak petani binaan menganggap penyuluh tersebut sebagai guru dan memberikan pendidikan khususnya ilmu tentang kegiatan agribisnis perikanan rumah tangga vaname.

Berbagai pihak yang tersebar di wilayah yang ingin menambah ilmu dan sekedar ingin tahu dari konsep RtVe yaitu dari: Kwanyar, Modung, Aceh, Tuban, Lamongan, Kalimantan, Pontianak, Blega, Kementerian Kelautan, Pasuruan, Bupati Bangkalan, DPR Pasuruan, mahasiswa, Wakil Bupati Pasuruan, Sampang, Pamekasan dan lain-lain.

\section{b. Fasilitator}

Peran penyuluh perikanan swadaya dalam agribisnis perikanan rumah tangga vaname (RtVe) salah satunya yaitu sebagai fasilitator. Fasilitator mempunyai artian sebagai orang yang menyediakan fasilitas yaitu memfasilitasi kebutuhan petani lain khususnya pada kegiatanagribisnis perikanan rumah tangga vaname di Kecamatan Kwanyar.

Petani udang yang tidak bisa membeli langsung ke tempat penjualan pakan dan benur dapat memesan melalui penyuluh perikanan swadaya. Penyuluh perikanan swadaya mendatangkan saprodi perikanan dari perusahaan dan ketika petani udang belum mencukupi dalam pembayaran saprodi perikanan tersebut maka diberikanan tenggang waktu pembayaran.

Penyuluh perikanan swadaya memfasilitasi dalam kegiatan agribisnis perikanan rumah tangga vaname (RtVe) mendatangkan saprodi perikanan seperti benur, pakan dan terpal didatangkan dari perusahaan CP Prima. Pakan dan benur tidak bisa secara langsung didatangkan dari perusahaan kepada petani udang, akan tetapi melalui petani yang dapat dipercaya seperti penyuluh perikanan swadaya tersebut. 


\section{c. Motivator}

Motivasi merupakan dorongan positif yang didapat dari dalam diri sendiri maupun dari luar. Motivasi memberikan alasan untuk melakukan sesuatu.Petani udang tentunya harus mendapat motivasi agar dapat melakukan kegiatan agribisnis perikanan dengan ikhlas dan maksimal. Salah satu sumber motivasi yang didapat dari luar oleh petani udang tersebut yaitu dari penyuluh perikanan swadaya.

Penyuluh perikanan swadaya di Kecamatan Kwanyar memiliki peran sebagai motivator, hal ini dapat mendorong petani untuk lebih semangat dalam menerapkan kegiatan agribisnis perikanan rumah tangga vaname (RtVe). Motivasi yang diberikan dengan cara yang tepat agar dapat meningkatkan semangat dan mendorong kembali petani untuk melakukan kegiatannya. Motivasi yang diberikan oleh penyuluh perikanan swadaya dilakukan secara langung, yaitu dengan menceritakan kesuksesan dalam kegiatan agribisnis perikanan rumah tangga vaname (RtVe).

\section{d. Teknisi}

Teknisi merupakan ahli teknik yang memiliki kemampuan dan kepandaian dan menguasai bidang teknologi tertentu yaitu dalam membuat dan merangkai sesuatu yang bekenaan dengan hasil hasil industri, seperti bangunan bangunan, mesin-mesin dan lain sebagainya.

Penyuluh perikanan swadaya berperan sebagai teknisi dalam penerapan rumah tangga vaname (RtVe).Teknisi lebih kepada awal pada konstruksi pembuatan kolam, setingan kincir air, dan titik central dalam pembuangan limbah udang.

Teknisi yang dilakukan yaitu mulai dari konstruksi tambak terpal. Pertama yaitu settingan kolam seperti penentuan titik central limbah, hal ini agar limbah yang dikeluarkan oleh udang di kolam dapat terkumpul dalam satu titik yang sudah dibuat seperti cekungan yang berada di tengah kolam yang sebelumnya di gali kurang lebih setengah meter, lalu kotoran tersebut dibuang lewat paralon yang sebelumnya berada di tengah cekungan tersebut agar air jadi bersih, apabila kotoran tersebut teraduk dengan air secara terus menerus maka akan menyebabkan stres pada udang. Kedua yaitu settingan kincir. Settingan kincir air selain penyuplai oksigen, kincir air bermanfaat untuk menggiring limbah yang dikeluarkan oleh udang ke titik central yang sudah dibuat di tengah kolam. Ketiga pembuangan limbah. Pembuangan limbah tidak langsung dibuang ke sungai akan tetapi diletakkan terlebih dahulu di tempat yang sudah disediakan agar tidak tercemar. Kotoran tersebut didiamkan, ketika sudah kering diambil lalu dibuang, akan tetapi kotoran tersebut bisa dijadikan pupuk dalam kegiatan di sektor pertanian.

\section{e. Penasihat}

Penasihat, untuk memilih alternatif perubahan yang paling tepat, yang secara teknis dapat dilaksanakan, secara ekonomi menguntungkan, dan dapat diterima oleh nilai-nilai sosial budaya setempat (Mardikanto, T, 1992). Nasihat yang diberikan penyuluh merupakan nasihat ketika ada permasalahan saat di lapangan. Nasihat diberikan kepada petani udang agar berhasil dalam kegiatan agribisnis perikanan rumah tangga vaname (RtVe) sesuai yang diharapkan dan mengurangi tingkat kerugian apabila ada suatu permasalahan yang masih belum ditemukan pemecahan masalahnya

Penyuluh perikanan swadaya memberikan saran apabila ada masalah yang ada di lapangan seperti terjadinya kematian udang, penyuluh perikanan swadaya memberikan saran agar panen parsial atau penambahan probiotik, apabila tingkat kematian tidak bisa diatasi maka diadakan panen paksa secara keseluruhan. Selain itu penyuluh perikanan swadaya memberikan anjuran agar bekerja dengan memperhatikan dampak terhadap lingkungan, sehingga tidak ada pencemaran lingkungan dalam kegiatan tersebut. 


\section{f. Pemantau}

Salah satu cara untuk melihat keberlangsungan, keberlanjutan dan kemajuan dari kegiatan agribisnis perikanan rumah tanggavaname (RtVe) yang dilakukan oleh petani udang yaitu dengan cara pemantauan.

Pemantauan merupakan suatu aktifitas yang bertujuan untuk memberikan informasi tentang sebab dan akibat dari kegiatan yang sebelumnya dilaksanakan. Pemantauan diperlukan agar kesalahan awal bisa diketahui dan dapat dilakukan tindakan perbaikan sehingga akan mengurangi risiko yang lebih besar.

Pemantauan yang dilakukan, secara tidak langsung akan terjadi komunikasi antara penyuluh perikanan swadaya dengan petani udang, sehingga dari kegiatan pamantauan terjadi sharing atau ngobrol bersama yang membahas kegiatan agribisnis perikanan rumah tangga vaname (RtVe). Tenaga untuk melakukan pemantauan kepada petani udang tidak mencukupi, dikarenakan tenaga yang masih belum mencukupi tersebut, maka diberlakukanlah pemantauan yang terkadang dibantu oleh anggota dari POKDAKAN bina usaha. Pemantauan juga dilakukan secara estafet yaitu bergantian antara petani satu dengan petani lainnya. Pemantauan yang dilakukan kepada petani udang, apabila sudah mencapai dua atau tiga siklus budidaya maka penyuluh perikanan swadaya mengurangi pemantauan kecuali adanya hal yang kritis di lapangan.

\section{g. Organisator}

Organisator, yang harus mampu menjalin hubungan baik dengan segenap lapisan masyarakat (terutama tokoh-tokohnya), mampu menumbuhkan kesadaran dan menggerakkan berpartisipasi dari masyarakat, mampu berinisiatif bagi terciptanya perubahan-perubahan serta dapat memobilisasi sumberdaya, mengarahkan da membina kegiatan kegiatan maupun mengembangkan kelembagaan-kelembagaan yang efektif untuk melaksanakan perubahan-perubahan yang direncanakan (Mardikanto, T, 1992).

Peran pernyuluh perikanan swadaya sebagai organisator yaitu menumbuh gerakkan partisipasi masyarakat dan mampu merubah masyarakat, perubahan perubahan tersebut seperti pengangguran masyarakat yang berada di Kecamatan Kwanyar sebagian kini beralih sebagai pekerja yang produktif.

\section{Kendala Penyuluh Perikanan}

Kendala merupakan suatu halangan maupun rintangan yang dapat mencegah dan menghalangi suatu pencapaian tujuan. Kendala bisa dikatakan sebagai segala hal atau sesuatu yang dapat menggagalkan suatu kesuksesan. Kendala bisa dapat membatasi suatu aktivitas dari pencapaian kinerja yang lebih baik dalam melakukan penyuluhan perikanan. Kendala saat melakukan penyuluhan perikanan yang dilakukan oleh penyuluh perikanan memberikan dampak terhadap keberhasilan penyuluhan yang sebelumnya sudah direncanakan. Dampak tersebut dapat menghalangi berbagai informasi atau wawasan yang disampaikan oleh komunikator (penyuluh) kepada komunikan (petani udang).

Pada pembahasan ini akan di uraikan tentang kendala dalam penyelenggaraan penyuluhan perikanan yang dilaksanakan oleh penyuluh perikanan PNS dan penyuluh perikanan swadaya.

\section{Kendala Penyuluh Perikanan PNS}

a. Jarak Tempuh

Penyuluh perikanan PNS terkena beberapa kendala saat melakukan penyuluhan perikanan salah satunya yaitu kendala jarak tempuh. Jarak tempuh dari kediaman penyuluh perikanan PNS cukup jauh dikarenakan berbeda kecamatan antara rumah penyuluh dengan tempat penyuluhan yang berjarak kurang lebih 27 kilometer.

Penyuluh perikanan PNS melakukan kunjungan dengan pulang dan pergi dari Kecamatan Burneh ke Kecamatan Kwanyar. Jadwal kantor penyuluh perikanan PNS da- 
lam satu minggu yaitu setiap hari senin dan hari jumat berada di kantor Dinas Kelautan dan Perikanan Kabupaten Bangkalan, sedangkan untuk hari selasa sampai kamis adalah jadwal penyuluh untuk kegiatan di lapang. Hari selasa sampai hari kamis digunakan penyuluh perikanan untuk ke lapangan, dalam tiga hari itu penyuluh perikanan PNS pulang pergi ke lapangan untuk melakukan kunjungan sesuai dengan rencana kerja yang sebelumnya sudah dibuat.

\section{b. Waktu}

Waktu merupakan kendala penyuluh perikanan PNS dalam melakukan kegiatan penyuluhan, jam kerja yang dimiliki penyuluh yaitu sampai sore hari. Petani udang mayoritas bisa berkumpul pada waktu sore dan malam hari, dari terkendalanya waktu tersebut memberikan dampak terhadap kegiatan penyuluhan, sehingga tidak semua petani mengikuti kegiatan penyuluhan.

Penyuluh perikanan PNS ketika ingin melakukan penyuluhan merasa waktu dinilai salah satu kendalanya. Setiap melakukan penyuluhan, petani yang datang tidaklah semua hadir, dikarenakan ada suatu kepentingan, ada beberapa petani yang bisa datang dan ada petani yang tidak bisa datang, bukannya petani tersebut tidak mau datang apabila ada penyuluhan, akan tetapi pada waktu siang hari terhalang oleh pekerjaan lainnya.

\section{c. Fasilitas}

Fasilitas merupakan salah satu kendala penyuluh perikanan PNS. Fasilitas dalam melakukan kegiatan penyuluhan perikanan dapat mendorong keberhasilan dan kesuksesan dalam melaksanakan kegiatan tersebut. Penyuluh perikanan PNS hanya memiliki jam kerja hingga sore hari dan mayoritas petani udang dapat ditemui pada waktu sore dan malam hari. Penyuluh perikanan PNS dalam menyiasati terkendalanya waktu tersebut berkeinginan untuk melakukan kegiatan penyuluhan di malam hari dengan kendaraan operasional roda empat yang dapat menjamin keamanan untuk menuju ke lokasi sasaran, akan tetapi fasilitas seperti mobil belum di dapat oleh penyuluh. Penyuluh peikanan PNS menilai lebih aman membawa mobil dikarenakan mobil dapat membawa orang banyak dan dapat menampung alat alat penyuluhan seperti laptop, proyektor, microphone dan lain sebagainya yang digunakan saat melakukan penyuluhan perikanan. Mobil juga dinilai lebih aman untuk mencapai ke tempat sasaran, dikarenakan tempat sasaran apabila berada di malam hari tidak terlalu aman untuk kendaraan roda dua.

\section{d. Jumlah Penyuluh}

Jumlah penyuluh perikanan PNS di Kecamatan Kwanyar dalam melakukan penyuluhan hanya dilakukan oleh satu orang penyuluh perikanan PNS dan dibantu oleh Penyuluh Perikanan Bantu (PPB) serta penyuluh lainnya. Penyuluh perikanan bantu tidak permanen memegang daerah Kecamatan Kwanyar, akan tetapi lebih kepada wilayah atau keseluruhan kecamatan yang berada di Kabupaten Bangkalan.

Penyuluhan yang dilakukan oleh penyuluh perikanan PNS yang berada di Kecamatan Kwanyar, dirasa kurang efektif karena kurangnya penyuluh tersebut, normalnya penyuluh dari pemerintah dalam satu kecamatan di pegang oleh tiga penyuluh perikanan PNS dan dibantu oleh PPB serta penyuluh lainnya. Hal ini kurang efektif juga apabila hanya ada satu penyuluh perikanan PNS dikarenakan di kecamatan Kwanyar ada 16 desa dan hanya di atasi oleh satu penyuluh perikanan PNS.

\section{e. Keilmuan}

Penyuluh perikanan PNS di Kecamatan Kwanyar hanya dipegang oleh satu penyuluh perikanan PNS. Satu penyuluh dirasa kurang efektif karena satu orang belum tentu dapat menguasai segala bidang keilmuan kelautan dan perikanan. Bidang ilmu yang diterapkan bukan hanya satu bidang perikanan saja, akan tetapi banyak bi- 
dang, seperti perikanan air tawar, perikanan air payau, perikanan air asin. Ilmu terapannya masih terbagi lagi, seperti pada bagian penangkapan, budidaya dan pengolahan. Spesifikasi ilmu tersebut hanya diatasi oleh satu orang penyuluh perikanan PNS sedangkan ilmu yang diterapkan cukup banyak. Latihan yang didapat oleh penyuluh perikanan PNS tidak rutin, sehingga berdampak pada keilmuan yang didapat oleh penyuluh perikanan PNS. Keilmuan tidak hanya satu ilmu penerapan akan tetapi banyak ilmu terapan yang harus penyuluh perikanan PNS kuasai atau paling tidak diketahui, sehingga penyuluh dapat mengetahui pemecahan masalah apabila ada masalah di lapangan saat melakukan penyuluhan perikanan khusunya pada udang vaname. Pelatihan dalam satu tahun bisa satu kali pelatihan, bahkan tidak ada pelatihan sama sekali. Keilmuan dirasa kurang oleh penyuluh perikanan PNS terlebih dalam menangani komoditas udang vaname.

Kendala Penyuluh Perikanan Swadaya Penyuluh perikanan swadaya saat dilapangan terkena beberapa kendala dalam melakukan penyuluhan. Kendala merupakan salah satu hal yang dapat menggagalkan tujuan yang sebelumnya sudah direncanakan oleh penyuluh perikanan swadaya, kendala tersebut memberikan dampak terhadap penerapan dan keberlanjutan dalam kegiatan agribisnis perikanan rumah tangga vaname (RtVe).

\section{a. Kendala Internal}

Kendala penyuluh perikanan swadaya dalam melakukan penyuluhan mengarah kepada pelaku utama kegiatan agribisnis perikanan rumah tangga vaname (RtVe) yaitu petani udang atau bisa dikatakan human error. Anggapan human error dikarenakan petani udang dalam budidaya udang vaname terkadang tidak sesuai dengan Standard Operating Procedure (SOP) yang sudah dilakukan pembinaan sebelumnya. Petani terkadang tidak mengikuti Standard Operating Procedure (SOP) yaitu pada tahap penumbuhan plankton ke transisi pene- baran benur. Petani terlalu terburu-buru dalam penebaran benur dan lebih mengikuti keinginan yang sudah ada dalam diri, yaitu keinginan untuk mendorong terus melakukan kegiatan agribisnis perikanan rumah tangga vaname (RtVe) agar mendapatkan keuntungan yang terus mengalir. Apabila petani menebarkan benur tanpa memperhatikan plankton yang tumbuh, hal tersebut akan mengakibatkan kematian terhadap udang, dikarenakan tidak ada pakan alami.

\section{b. Kendala Eksternal}

Kendala eksternal yaitu adanya pihak luar yang mempunyai kepentingan di dalam kegiatan agribisnis perikanan rumah tangga vaname (RtVe) yang mengakibatkan keberlanjutan kegiatan agribisnis perikanan rumah tangga vaname (RtVe) tidak stabil. Pihak yang berkepentingan yaitu ingin menguasai hal tertentu sesuai dengan keinginan pribadi. Ketika petani udang vaname dengan penyuluh perikan swadaya diajak bekerja sama, adanya intervensi pihak luar memberikan dampak yaitu menghambat dari kerja sama tersebut.

Penyuluh perikanan swadaya memberikan tawaran untuk bekerja secara bersama-sama, seperti dahulu. Dahulu ketika awal kegiatan agribisnis perikanan rumah tangga vaname (RtVe) pada tahap tebar benur dilakukan secara bersama-sama atau serentak. Adanya intervensi pihak luar mengakibatkan perpecahan. Penebaran benur menjadi tidak serentak, dari penebaran yang tidak serentak tersebut mengakibatkan penyakit gampang masuk.

\section{KESIMPULAN}

1. Pelaksanaan penyuluhan perikanan yang dilaksanakan oleh penyuluh perikanan PNS menggunakan sistem LAKU, metode yang digunakan yaitu kontak tani dan menggunakan metode pertemuan. Materi yang digunakan oleh penyuluh perikanan PNS didapat dari internet. Perlengkapan penyuluhan menggunakan laptop, HP, proyektor dan microphone. 
Rencana penyuluhan perikanan yaitu Rencana Kerja Tahunan Penyuluh (RKTP) didapat dari Badan Koordinasi Penyuluhan (BAKORLUH). Evaluasi yang dilakukan yaitu evaluasi sumatif. Pelaksanaan penyuluhan perikanan yang dilaksanakan oleh penyuluh perikanan swadaya menggunakan metode person to person dan dengan metode pertemuan umum. Materi yang digunakan oleh penyuluh perikanan swadaya didapat dari pengalaman berbudidaya dan dari pihak swasta. Perlengkapan penyuluhan yang digunakan oleh penyuluh perikanan swadaya menggunakan laptop. Rencana kerja penyuluhan dilakukan secara spontan. Evaluasi yang dilakukan yaitu evaluasi sumatif.

2. Secara umum, penyuluh swadaya lebih berperan dibandingkan dengan penyuluh PNS. Hal itu terjadi karena penyuluh swadaya lebih mendasarkan materi penyuluhan pada hasil trial and error pada usaha perikanan. Peran penyuluh perikanan PNS dalam agribisnis perikanan rumah tangga vaname (RtVe) yaitu penyampaian informasi, jembatan penghubung, pembimbing dan penganalisa. Peran penyuluh yang sudah optimal yaitu sebagai pembimbing dan penganalisa, sedangkan yang kurang optimal yaitu penyampaian informasi dan menghubungkan dengan tengkulak. Peran penyuluh perikanan swadaya sudah optimal yaitu peran sebagai pendidik, peran sebagai fasilitator, peran sebagai motivator, peran sebagai teknisi, peran sebagai penasihat, peran sebagai pemantau dan peran sebagai organisator.

3. Kendala penyuluhan perikanan oleh penyuluh perikanan PNS yaitu kendala jarak tempuh, kendala waktu, kendala fasilitas, kendala jumlah penyuluh dan kendala keilmuan. Kendala penyuluhan perikananan oleh penyuluh perikanan swadaya yaitu kendala internal dan eksternal. Kendala internal yaitu kendala human error. Kendala eksternal yaitu kendala intervensi pihak luar yang mempunyai kepentingan pribadi.

\section{DAFTAR PUSTAKA}

Akhmad, Ika dan Wiwik. 2013. Perencanaan dan Perancangan Pusat Pengembangan Budidaya Ikan Bandeng Tambak di Sidoarjo. Vol 17(1).

Ban, V, D dan Hawkins. 1999. Penyuluhan Pertanian. Yogyakarta: Kanisius.

Departemen Pertanian, 2007. Peraturan Menteri Pertanian Tentang Pedoman Kelmbagaan Pertanian. Jakarta.

Fauzi A. 2005. Kebijakan perikanan dan kelautan (Isu, Sintesis, Dan gagasan). Jakarta: PT Gramedia Pustaka Utama.

Galuh dan Ivan. 2014. Arahan Pengembangan Agribisnis Kota Pagaralam, Provinsi Sumatera Selatan. ISSN: 2460-6480.

Hermansyah. 2015. Peran Kepala Desa Dalam Pelaksanaan Pembangunan Kecamatan Tana Lia Kabupaten Tana Tidung, (Studi Kasus di Desa Tanah Merah dan Desa Sambungan). Vol. 3(2).

Kharisma A, dan Abdul. 2011. Kelimpahan Bakteri Vibrio sp. Pada Air Pembesaran Udang Vannamei (Litopenaeus vannamei) Sebagai Deteksi Dini Serangan Penyakit Vibriosis. Surabaya. Jurnal Ilmiah Perikanan dan Kelautan. Vol 4(2).

Mardikanto, T. 1992. Penyuluhan Pembangunan Pertanian. Surakarta: Sebelas Maret University press. 
Republik Indonesia. 2006. Undang-Undang No. 16 Tahun 2006 Tentang Sisten Penyuluhan Pertanian, Perikanan dan Kehutanan. Jakarta.

Safrida, T, Makmur dan Hafid. 2015. Peran Penyuluh Perikanan Dalam Pengembangan Sektor Perikanan Di Kabupaten Aceh Utara. Agrisep. Vol. 16(2).

Sugiyono. 2008. Metode Penelitian Kualitatif Pendekatan Kuantitatif, Kualitatif, dan R\&D. Bandung: Alfabeta, cv.

Sugiyono. 2014. Merode Penelitian Kombinasi (Mixed methods). Bandung: Alfabeta, cv.

Supono. 2011. Optimalisasi Budidaya Udang Putih (litopenaeus vannamei) Melalui Peningkatan Kepadatan Penebaran Di Tambak Plastik. Lampung. Vol 29 (1). 